\title{
Resources of Tourism Demand in Tartous Governorate, Syrian Arab Republic
}

\author{
Hanadi M. Makhlouf ${ }^{1}$, Liudmila A. Guzikova ${ }^{2 *}$, and Younan Radwan ${ }^{1}$ \\ ${ }^{1}$ University of Tishreen, Syrian Arab Republic \\ ${ }^{2}$ Peter the Great Saint-Petersburg Polytechnic University, Russian Federation
}

\begin{abstract}
Availability of tourism resources is the main condition to meet the needs of the tourism. When tourism resources are properly managed and invested enough they become the base of physical and cognitive activity for the humans and contribute to the economic prosperity of the territory. This applies in particular to the Syrian Arab Republic and the Tartous governorate located in the eastern Mediterranean. In the article the factors determining tourism demand in the Tartous governorate are studied. The results of the investigation allowed formulating recommendations for the development of tourism in Tartous governorate.
\end{abstract}

\section{Introduction}

The tourism is closely connected with the physical activity of the humans, and the natural, historical and cultural, social and economic features of the certain territory serve as the incentive for this activity. Tourism is also one of the economic activities having a great importance across the world. In the economies of many countries, tourism has become an industry providing the large part of the national product and consuming for this purpose various types of resources. For the recent decades before the Covid-19 pandemic the popularity of tourism grew rapidly so the tourism was the one of the fastest growing economic sectors.

Weber (1991) wrote that despite the tremendous growth of knowledge about tourism there is still a number of problem areas opening up a number of questions related with the development and the adaption of different measuring techniques, research instruments and analysis methods. Though this conclusion was made back in the 20th century there are no reasons to suppose the number of problems diminished significantly.

According to (Camillieri, 2018) the demand for tourism may be affected by the marketing mix elements, including the nature of the product or service, its distribution, its promotional strategies and its price. But the tourism products and services in turn are based on the various resources of the destination which should be preliminary studied for the proper positioning.

As the example of the demand resources examination for developing and branding tourism in the certain territory the studies (Tanina, Zaborovskaia, Tschelkina, 2018; Tanina, Zaborovskaia, Shabunina, Yakishin, 2018) may be mentioned.

* Corresponding author: guzikova@mail.ru 
The development of tourism requires the presence of the tourism demand resources conducive to the implementation of tourist activities and the certain type of tourism. These resources may be considered as the stock of raw materials that exceeds the needs of the local population. The importance of the study for the spatial development of tourism in the Tartous governorate is based on the provision above. The tourism is determined by the socio-economic factors associated with natural resources and cultural and historical resources, therefore the factors should be analysed taking into account their economic and social role to identify those critical for the development of tourism and recreation in the Tartous governorate.

The aims of the current research are the following:

- to identify the tourism resources which help to develop the tourism spatial organization of the territory;

- to study and to rev reveal resources that can meet tourism demand in Tartous.

- to identify the natural resources and cultural and historical resources in the Tartous governorate.

- to determine the socio-economic conditions and opportunities of the Tartous governorate.

\section{Methodology and Data}

Research methodology includes

- Inductive method used to address the factors meeting the tourism demand and contributing in the development of tourism;

- Deductive method used for linking the identified factors to their roles in completion tourist demand in the territory under investigation and for linking them logically and scientifically to address the role of tourism resources in the creation of tourist demand in whole.

The information on geographical and spatial characteristics of Tartous governorate was accessed from (Department of Regional Planning, 2010). The information about the population was accessed from the Results of Population Census and the Results of Families Surveys and the Labour Power Research held by the Central Bureau of Statistic of the Syrian Arab Republic. The data from General Institute of Roads Communication, Department of Tourism and Department of Museums and Antiquities in Tartous were used to describe natural and cultural conditions and tourist service and facilities of Tartous governorate.

\section{Main Results of Study}

Tourism is an important component of the economy of many countries by ensuring the employment of local people and increasing the national product. The tourism resources are the facilities and phenomena of natural or human-made origin that can be used to meet the tourism demand and to satisfy the needs and wishes of tourists (Khadrah, 2006). The availability of tourism resources has impact of on the spatial development of the tourism activities, formation of the tourism regions, their specialization and effective economic development.

Tourism resources may be divided into three groups: a) natural, b) historical and cultural, c) social and economic. The access to these groups of resources is organized through tourism services and facilities which contribute the general result of the tourism for the territory. 
The map (Fig. 1) shows the study area - Tartous governorate. Geographically Tartous governorate is situated on the eastern coast of the Mediterranean west of the Syrian Arab Republic extended $90 \mathrm{~km}$ along the coast of the Mediterranean with an area of $1896 \mathrm{~km}^{2}$. Tartous governorate: is located at the longitude $54^{\circ} 35^{\prime}-\left(20^{\circ} 36^{\prime}\right.$ east of Greenwich), the latitude $38^{\circ} 34^{\prime}\left(16^{\circ} 35^{\prime}\right.$ north of the equator).

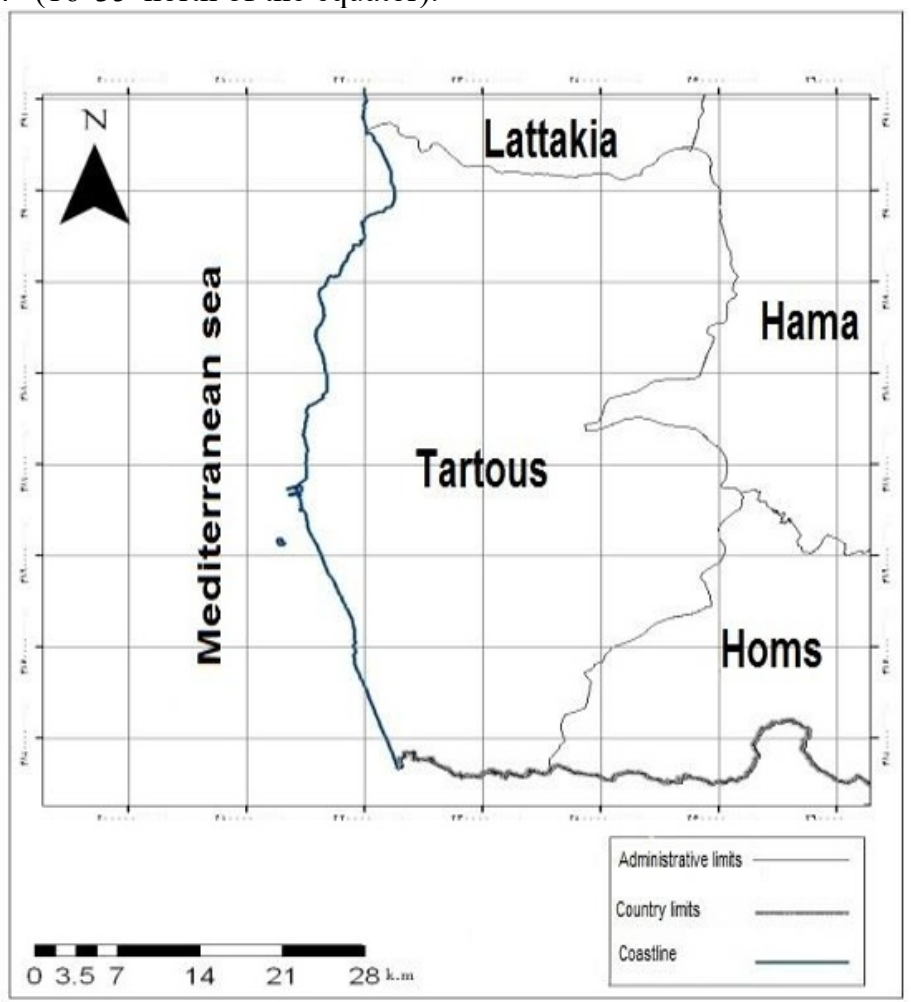

Fig. 1. The map of Tartous governorate drawn by GIS 9.3.

\subsection{Natural Tourism Resources of Tartous Governorat}

In tourism activity the natural resources have exclusive importance and specificity. The availability of land areas with various landscapes, beaches, mountains, forests and aquatic constitutes the conditions for tourism development in general and for certain types and forms in particular, for building the objects of service and accommodation and transport network. Thus natural resources are the part of the physical base of tourism (Khadrah, 2017).

Location. Map of the Fig. 2 shows the location of Tartous governorate in the Syrian Arab Republic. Its geographical location plays the significant role in the development of tourism due to the proximity to the main attractions (Hawamdah \& Alhemyari, 2003). Tartous governorate has the wide geographic diversity - the seaside and coastal plains and the area of the coastal mountains, and climatic diversity which varies between the coastal and mountain areas through the seasons of the year and is clearly different in summer and winter.

In the southern part of the governorate the only inhabited island is situated - the island of Arwad, which is $3 \mathrm{~km}$ from coast and $5 \mathrm{~km}$ from Tartous. Tartous governorate is allocated from the Mediterranean to the borders of governorates of Lattakia, Homs and Hama 


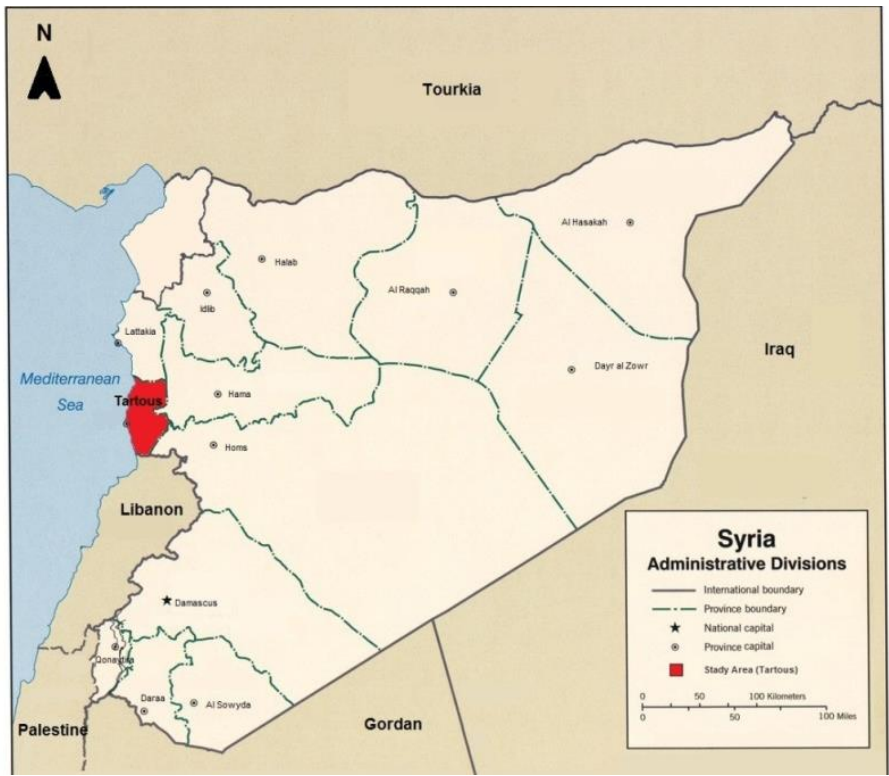

Fig. 2. Location of Tartous governorate in the Syrian Arab Republic.

Terrain. The region of Tartous is divided into three terrain areas: the coast and coastal plains, the highland area and the high mountain area, which is at maximum altitude of more than 1,300 m. Most of the mountains are covered with forest. The rich diversity in terrain gives the Tartous governorate a lot of tourist attractiveness and makes it an interesting destination for those who enjoy the view of the sea and the mountains. (Adel, 2003).

Climate. The climate is the major natural resource that has impact on tourism. The region of Tartous has a favourable climate for tourist activities in the different seasons of the year. This is of the utmost importance in determining the length of the tourist season. In tourism areas of Mediterranean the climate is moderate on the coasts and oblique to cold on the mountain heights. The winter is mild on the coast and with snow falling on mountain heights. There is an annual rain of $1000 \mathrm{~mm}$ in Tartous governorate territory, in some areas - up to more than $1800 \mathrm{~mm}$. This is significant for providing the right atmosphere for recreation and enjoyment of the nature and for creating means for attracting tourists as well.

Water Resources. Water resources are considered as tourist attraction factor. The landscapes with water objects are the favourite place of rest and recreation for tourists and vacationers. Due to the abundance of rain and snow, Tartous governorate is rich in water sources which include rivers, springs and lakes.

There is a river of constant flux - the Big River $50 \mathrm{~km}$ long - in the south of the governorate territory. This river is fed by rain and snow and absorbs several smaller rivers of temporary flux and falls to the Gulf of Akkar of Mediterranean Sea. The basin of the Big River includes the Al Surani, Al Ghamka, Al Balout, Al Abrash, Al Khawabi and some other rivers (Adel, 2003).

There are several springs in the Tartous governorate distributed throughout the region. The most importantt of these are: Durkaysh Spring, Al Surani Spring, Al Di'a Spring, Al Fawar Spring, Raas Al Nabe'h Spring and Al Ghamkah Spring.

The lakes are an important tourist resource also. There are several natural lakes - Al Basel, Khalifah and Al Surani - in the region of Tartous.

Natural water resources are the attractive factor for tourism and moreover - they are connected with serving the needs of tourists' everyday life (Hadjikakou, Miller, 
Chenoweth, Druckman, Zoumides, 2015). Becken (2014) found that in the countries of low or medium income the average level of the water consumption of tourists exceeds that of local inhabitants while in the high income regions the consumption of water of the tourists and locals is approximately the same.

Nature Reserves. The reserves are the base of eco-tourism which relatively recently became known about as a new type of tourist activity. The eco-friendly practice of the humans is aimed to take care of the inheritance of innate natural and cultural environment in which they live. There are three nature reserves in Tartous governorate with the total area of forest land and forestry equal to $31000 \mathrm{ha}$, attractive for tourists due to their richness and density of tree species and being served by good roads.

Table 1. Natural reserves of Tartous governate.

\begin{tabular}{|l|l|c|c|l|}
\hline \multicolumn{1}{|c|}{ Reserve } & Zone & $\begin{array}{c}\text { Distance from } \\
\text { Tartous, } \mathbf{~ k m}\end{array}$ & $\begin{array}{c}\text { Total Area, } \\
\text { Hectare }\end{array}$ & \multicolumn{1}{|c|}{ Characteristics } \\
\hline $\begin{array}{l}\text { Sha'arat } \\
\text { Alsharqya }\end{array}$ & Al Kadmous & 70 & 1000 & $\begin{array}{l}\text { richness of natural forest } \\
\text { vegetation }\end{array}$ \\
\hline $\begin{array}{l}\text { Al Nabi } \\
\text { Matah }\end{array}$ & Durkaysh & 53 & 650 & $\begin{array}{l}\text { mixed forest with the rich } \\
\text { vegetation and permanent } \\
\text { water springs }\end{array}$ \\
\hline $\begin{array}{l}\text { Qala'at Al } \\
\text { Kahf }\end{array}$ & Shikh Badr & 50 & 26 & $\begin{array}{l}\text { mountain plateau by the } \\
\text { Qala'at Al Kahf, which is a } \\
\text { landmark, surrounded by } \\
\text { valleys and near settlements }\end{array}$ \\
\hline
\end{tabular}

Forests. There are many forests in Tartous governorate. Most of these forests are easy to access what makes them viable for tourists who like nature and sport, mountain and ecotourism. The mountain forests are the objects of interest in Al-Kadmous and Sheikh Badr, and Mashta Al-Houlu. In addition to the woodland and mountains attracting the large number of visitors on weekends and in the holidays and seasons there is a number of open sites which represent the richness of nature and increase the attractiveness of the near woodlands such as Taleh Forest, Al Kadmous Forest and Serstan Forest.

\subsection{Cultural and Historical Tourism Resources of Tartous Governorate}

Cultural and historical resources have a special place within the group of tourism resources. Cultural resources include cities and countryside which are the legacy of the social evolution and are important for the various types of cultural tourism activities. The prominent cultural and historic monuments and sites, castles, fortresses and towers, archaeological sites and museums represent a key tool to meet the needs of cultural tourism in Tartous governorate.

Archaeological cities. The archaeological sites of the territory are divided into six grades according to their scientific importance or quantity of the monuments. Tartous governorate has resources for historical tours to the urban civilization of the ancient time, the most important of which are Tartous, Arwad and Amrit.

Castles. The castles illustrate the history and have symbolic meaning also. The most important castles in Tartous governorate are the Castle of Markab, the fortress of Arwad Castle, the Castle of Safita and the Castle or Al-Hawash.

Forts. There are several forts in Tartous governorate, the most prominent of which are Fort Suleiman and Fort Marqiya.

Museums. The Museum of the Old Cathedral in Tartous (Notre Dame Tartous) and the Sheikh Saleh Museum have collections of artefacts illustrating the history and culture of the region. 
Towers. Towers were the places of surveillance important to improve the safety of cities since antiquity. The following towers are available for sightseeing: Al Tahouna Tower, 'Asour Tower, Umm Hosh Tower, Bejmaash Tower, Tekheh Tower and Mi'ar Tower.

Traditional Markets. The markets of traditional crafts that distinguish each area from the others and represent the most important crafts are characteristic for Tartous governorate. The boat producrion on the island of Arwad is inherited from parents and grandparents. This craft put the beginning for the marine industry, for the other branches of the offshore industry and for crafts in many villages. In the area of Sheikh Badr, and Al Kadmous the dishes making of straw and the pottery industry are developed. Production of the natural silk exists in Durkaysh.

Folk festivals. The folklore representing the image of the prevailing social life in Tartous governorate is the outcome of the history and civilizations of the Turkish coastline. The folklore and everything that falls under the designation of customs and traditions of the inhabitants of the region in all fields of the lifestyle and behaviour, all that human community can express by dancing and singing, folk music, folk clothes, folk concerts, special social events (weddings), food and drinks are represented in the festivals of the folk art.

\subsection{Socio-economic Resources of Tartous Governorate}

The economic situation of the territory may be considered as the factor of tourism attractiveness - some categories of tourists are seeking for shopping and/or investment opportunities, for stay in the comfortable conditions and for high level of service.

The lifestyle, habits and traditions of local population not only form an important part of total impression and of the environment of tourists' stay but become an attractiveness factors themselves. In turn, tourism has the great impact on the economic and social life and habits of the local inhabitants so tourism sector should have responsibility for protection and saving the local social and economic stability.

Economic and Geographic Location. Tartous governorate is distinguished by its important geographical location, as it constitutes the gateway to the Syrian Arab Republic and to the countries of the Mediterranean basin. The ports Tartous and Baniyas are the most important marine windows for import and export to and from Syria and open a transit gate between the west and east and the states of the Gulf and Iraq. Besides the economic importance, both Tartous and Baniyas are situated on the seashore where geographical and topographical nature, the abundance of water, the fertility of the land and the proximity of the countryside and Arwad Island which enjoy a picturesque nature. Thus we find that the geographic location of Tartous governorate provides the easy access to its territory and to its richness in tourist sites.

Population Composition and Geospatial Distribution. In the recent decades the significant changes have occurred in the composition of the population in Tartous governorate. In general population grows. Due to the continuous gradual decline in fertility rate during the past four decades the proportion of children under 15 years of age declined while the proportion of the population of working age from 15 to 64 years and the proportion of the elderly (as a result of the sharp decline in mortality rate) increased. The average general population density in Tartous governorate equals to 530 people $/ \mathrm{km}^{2}$. Tartous has the largest share of population which constitutes about $40.5 \%$, followed by the Baniyas region, then Safita, Duraykish, Sheikh Badr, and Kadmous. It should be noted that $46 \%$ of the total population of the governorate is located in the areas with waterfronts.

As for the gender composition of the population, the sex ratio that expresses the number of males for every 100 females decreased in the governorate from 104.5 in 1994 to 102.6 in 
2010 (the last population census) and the decrease in this percentage indicates continued migration flow out of the governorate, especially the males of working age.

Urbanization. The governorate lands include two domains. The first is the built-up field that includes all man-made components regardless of their functions - buildings roads - ports - installations. The second includes the open field - all the remaining agricultural and natural lands. During the recent half of a century the built up area in Tartous governorate increased but the human settlement and economic activity are concentrated in the coastal region. As the result the ratio of the built-up field to the open field in the Tartous governorate is greater than in the rest of the governorates of Syria.

\subsection{Tourist Services and Facilities of Tartous Governorate}

Tourism services are divided into two basic types: tourism infrastructure services and means of transportation, the level of development of the transportation network and the ease of transportation access to tourism areas.

Tourism Infrastructure Services. Formica \& Kothari (2008) mention that as the world moves to electronic business, the most important changes are related to the choice of innovative marketing tools based on their capacity to add value of the destination. According to (Khadrah, 2018), tourism industry includes electronic means: electronic commerce websites and review of travel websites and electronic commerce specialized in the sale of travel products. This is the basis for the organized tourism development as it creates all appropriate conditions in order to provide a full range of services for tourists (accommodation, feeding, transportation, flights). The tourism offer consists of two main elements, the first of which is the attractions and the second is the tourism facilities and services, which are necessary to provide the access to the attractions.

Ease and convenience of tourism increase the length of tourists' stay and evoke desire to return to the tourist site again. Otherwise, when the level of services and tourism facilities provided is poor this makes the negative impact on the general impression of tourists and undermines the reputation of the tourism destination as the whole. Almost all the lands of Tartous governorate are the summer resort because of the beauty of the natural formations and the roads that reach all the attractive sites. The Tartous governorate is able to receive large number of tourists providing them with all resort services, swimming pools and beaches and chalets, hotels, restaurants (Jarjour, 2011).

Means of Transportation, the Level of Development of the Transportation Network and the Ease of Transportation Access to Tourist Areas. Transportation is the main pillar of tourism activity linking the tourism sites of the governorate. Geographical location of Tartous governorate contributes to the development of transport which represents an important tourism resource. Besides the international transit road $(81 \mathrm{~km}$ long section of the highway) there is a road network linking the regions within the territory adjacent to the sea coast and connecting them with the rest of the provinces. Central road (Tartous - Al-Mantar) connects the governorate with Lebanon through the Al-Arida border post and has a length of more than $27 \mathrm{~km}$. The distance between Tartous, the capital city of the governorate, and the main areas exceeds $196 \mathrm{~km}$. The international transit road passing through Tartous governorate has 12 road junctions.

The transportation means contribute to developing tourism in Tartous governorate and may have a positive role in increasing the number of tourists coming from other provinces, neighboring countries and foreign tourists. The port of Tartous is considered a tourist port as well as a commercial. The modern hall equipped with everything necessary to receive and provide services for travelers was opened recently. The area of this hall is approximately $2000 \mathrm{~m}^{2}$ and includes the waiting section, section for travelers, snack bar and tourist information office. 
To meet the tourism demand and help to increase the tourist flow and renew it constantly, to provide the effectiveness of the tourism sector it is important to have the appropriate human resource. Tartous governorate possesses the human resources to provide tourism services as it has a large share of the working age population of 15-64 years old with the large number of them experienced in tourism and hotel services. This allows Tartous governorate meeting the needs and requirements of tourists the best way and makes it a prospective tourism destination.

\section{Conclusions}

Tartous governorate has all kinds of resources to meet the tourism demand and this is the decisive factor for the successive spatial development of the tourism sector. Tartous governorate has tourism advantages due to its strategic location and the diversity of its attractions. The diversity of the tourism items which are represented by the historical, cultural, environmental and natural archeological components gives the Tartous governorate a comparative competitive advantage compared to other governorates.

Tourism resources affect the spatial organization of tourism activities and the formation of regions and tourist centers, their specialization and economic effectiveness, but this effect is indirect through social and economic factors, especially the size and structure of tourism demand. Despite the importance of historical and cultural monuments in the structure of tourism resources, the bounties of nature occupy the most prominent place and are the basic material components of tourism.

Today the activities and measures for the tourism management in Tartous governorate are mostly of the same type and are not sufficient in number and range and do not cover all locations in the governorate which calls for more cooperation between tourism directorates and local public and private departments in tourism areas far from the center of the governorate to establish attractive tourism activities.

The increase of the effective employing the natural, historical and cultural components is the way to develop tourism in Tartous governorate. The lack of an effective system through which the tourism demand resources can be managed in a purposeful and effective way to achieve the sustainability of tourism activity prevents the tourism development in Tartous governorate.

Systematic efforts are needed to support and increase the interest in the many strong tourism attractions found in Tartous governorate and to provide the sustainable tourist flow in Tartous governorate. The strategy for economic and social development of Tartous governorate should provide for activating all the tourism services to achieve the tourist diversity in a way that suits the tourism potential of the region and should take to account the opportunities and threats caused by the growth of the tourism supply and demand.

The tourism products in Tartous governorate should be diversified to engage the resources of tourism demand and to attract different types of tourists who are interested in the new types of tourism maintaining an integrative framework with traditional patterns of cultural tourism.

The plans to develop socio-economic factors in Tartous governorate should be adopted within a comprehensive framework for all tourist sites. Increasing the development of infrastructure should be organized in proportion to the available tourism resources in order to meet the needs of tourists coming to Tartous governorate. The attention should be paid to tourist guides, as this profession reflects the country's interest in tourism development and introduces visitors to the various components of tourism attraction of the Tartous governorate. Tartous governorate is characterized by traditional handicrafts, which are an important tourist attraction, and therefore the sales which provide direct sources of income 
for the inhabitants of the governorate, should be developed in a manner compatible with the tourism demand.

The results of the research create the base tor the detailed elaboration the viable policy to meet the needs of the tourists and to provide adequate attention and development for the natural, cultural and historical resources of the tourist demand. The results may be also useful for spatial organization of the tourism sector in Tartous governorate and for ensuring better tourism services through the development of socio-economic conditions and resources.

\section{References}

1. A. Adel. The Natural Geography of Syria, Tishreen University. (2003).

2. S.Becken. Water equity - Contrasting tourism water use with that of the local community. Journal of Sustainable Tourism Volume Water Resources and Industry, 78, pp. 9-22. ( 2014)

3. M.A. Camillieri. Tourism Supply and Demand, In Travel Marketing, Tourism economics and Airline Products (Chapter 8, pp, 139-154), Cham, Switzerland, Springer Nature. (2018)

4. Department of Regional Planning. The geographical and spatial location of Tartous governorate, Tartous Town Council. (2010)

5. S. Formica, T. H. Kothari. Strategic Destination Planning: Analyzing the Future of Tourism. Journal of Travel Research, 46, 355-367. (2008)

6. M. Hadjikakou, G.Miller, J. Chenoweth, A. Druckman, C. Zoumides. A comprehensive framework for comparing water use intensity across different tourist types. Journal of Sustainable Tourism, 23(10), pp. 1445-1467. (2015)

7. N. Hawamdah, M. Alhemyari. Tourism Geography in the 21 Century, Jordan. (2003)

8. F. Jarjour. Statistical Study for Tartous governorate, Tourism Study. (2011)

9. J: Khadrah. Geography of tourism and Services, University of Tishreen. (2006)

10. J: Khadrah. The Tourism Economy, Algeria, (2017)

11. J: Khadrah. The Electronical Tourism, Algeria. (2018)

12. A. Tanina, O. Zaborovskaia, T. Shabunina, Y. Yakishin. Conceptual bases of development of tourism in municipal formation (on an example of Gatchina municipal area, in Proceedings of the 32nd International Business Information Management Association Conference, 3216-3222. (2018)

13. A. Tanina, O. Zaborovskaia, S. Tschelkina. Features of the formation of the tourist brand of the municipal formation, in Proceedings of the 32nd International Business Information Management Association Conference, 3244-3252. (2018)

14. S. Weber. Problem areas and sources of errors in tourism demand research. The Tourist Review, 46(3), pp. 2-8. (1991). 